\title{
Effects of anoxia and sulfide on concentrations of total and methyl mercury in sediment and water in two Hg-polluted lakes
}

\author{
Olof Regnell, Tommy Hammar, Anders Helgée, and Bo Troedsson
}

\begin{abstract}
Between May and December 1996, monthly samples of surface sediment $(0-1 \mathrm{~cm})$, settling matter, and water were taken at a shallow site and a deep site in each of two consecutive Hg-polluted riverine lakes. In the upper lake, the sediment was polluted also with cellulose fiber. Both hypolimnia turned anoxic, but sulfide was detected only in the upper lake. When sulfide appeared, hypolimnetic methyl mercury (MeHg) increased and reached $47 \mathrm{pM}$ (9.4 ng. $\mathrm{L}^{-1}$ ), whereas $\mathrm{MeHg}$ in the sediment below decreased. The increase in hypolimnetic inorganic $\mathrm{Hg}$ ( $\mathrm{IHg}=$ total $\mathrm{Hg}-\mathrm{MeHg}$ ), which reached a peak of $40 \mathrm{pM}\left(8.0 \mathrm{ng} \cdot \mathrm{L}^{-1}\right)$, was slower, possibly because mobilized IHg was methylated. In the lower lake, hypolimnetic $\mathrm{MeHg}$ and $\mathrm{IHg}$ increased less dramatically during summer stratification, reaching only 5 and $24 \mathrm{pM}\left(1.0\right.$ and $\left.4.8 \mathrm{ng} \cdot \mathrm{L}^{-1}\right)$, respectively. There was no detectable concomitant decrease in sediment $\mathrm{MeHg}$. In both lakes, MeHg appeared to increase simultaneously with total Fe and $\mathrm{Mn}$ in the hypolimnion, as did $\mathrm{IHg}$ in the lower lake. Our observations suggest that the presence of hydrous ferric and manganese oxides decreased the mobility of $\mathrm{Hg}$ in both lakes but increased $\mathrm{MeHg}$ production in the upper lake.
\end{abstract}

\begin{abstract}
Résumé : De mai à décembre 1996, nous avons prélevé à chaque mois des sédiments de surface $(0-1 \mathrm{~cm})$, de la matière en sédimentation et de l'eau à un site de faible profondeur et à un site plus profond dans chacun de deux lacs fluviaux situés en enfilade et pollués au Hg. Les sédiments du lac d'amont étaient aussi contaminés par des fibres de cellulose. Les hypolimnions des deux lacs sont devenus anoxiques, mais le sulfure n'a été détecté que dans le lac d'amont. À l'apparition du sulfure, le méthyl-mercure $(\mathrm{MeHg})$ s'est accru et a atteint $47 \mathrm{pM}\left(9,4 \mathrm{ng} \cdot \mathrm{L}^{-1}\right)$ dans l'hypolimnion, alors qu'il a diminué dans les sédiments sous-jacents. L'accroissement du $\mathrm{Hg}$ inorganique ( $\mathrm{Hg}=\mathrm{Hg}$ total $-\mathrm{MeHg})$ dans l'hypolimnion s'est fait plus lentement avec un maximum à $40 \mathrm{pM}\left(8,0 \mathrm{ng} \cdot \mathrm{L}^{-1}\right)$, probablement parce que le Hg libéré a subi la méthylation. Dans le lac d'aval, le MeHg et l'IHg de l'hypolimnion ont crû de façon moins spectaculaire pendant la stratification d'été, atteignant respectivement seulement $5 \mathrm{pM}\left(1,0 \mathrm{ng} \cdot \mathrm{L}^{-1}\right)$ et $24 \mathrm{pM}\left(4,8 \mathrm{ng} \cdot \mathrm{L}^{-1}\right)$; il n'y a pas eu de chute concomitante du MeHg dans les sédiments. Dans les deux lacs, l'accroissement du MeHg s'est accompagné d'une augmentation du Fe total et du Mn dans l'hypolimnion; il en a été de même dans le cas du IHg du lac d'aval. Nos observations laissent croire que la présence d'oxyde ferrique hydraté et d'oxyde de manganèse a diminué la mobilité du Hg dans les deux lacs, mais qu'elle a augmenté la production de $\mathrm{MeHg}$ dans le lac supérieur.
\end{abstract}

[Traduit par la Rédaction]

\section{Introduction}

Mercury is a nonessential heavy metal that is highly toxic to all organisms. Its monomethylated form, methyl mercury $(\mathrm{MeHg})$, is a human health concern and poses a threat mainly to those with a high intake of piscivorous freshwater fish. $\mathrm{MeHg}$, as opposed to inorganic $\mathrm{Hg}(\mathrm{IHg}=$ total $\mathrm{Hg}-$ $\mathrm{MeHg}$ ), is highly bioaccumulated in aquatic food chains and

Received July 5, 2000. Accepted December 1, 2000.

Published on the NRC Research Press Web site on February 23, 2001 .

J15854

O. Regnell. ${ }^{1}$ Department of Ecology, Ecotoxicology, University of Lund, Sölvegatan 37, S-223 62 Lund, Sweden. T. Hammar. Kalmar County Administration, Environmental Unit, S-391 86 Kalmar, Sweden.

A. Helgée. Hultsfred Municipality, Environment and Health Office, Box 500, S-577 26 Hultsfred, Sweden.

B. Troedsson. Vetlanda Municipality, Box 53, S-574 21 Vetlanda, Sweden.

${ }^{1}$ Corresponding author (e-mail: olof.regnell@ecotox.lu.se). may reach concentrations in fish six to seven orders of magnitude higher than in water (Driscoll et al. 1994).

Mercury is transported in rivers in both dissolved and particulate form, the particulate fraction increasing during high flow (Jackson et al. 1982). When a river passes through a lake, a major part of the particle-bound $\mathrm{Hg}$ may settle to the bottom, whereas dissolved forms may be scavenged by seston, notably phytoplankton (Kirkwood et al. 1999), and thereafter settle to the bottom. Dissolved $\mathrm{Hg}$ is also adsorbed directly by bottom sediment, volatilizes, or is simply transported out of the lake with outflowing water.

Several processes interfere with $\mathrm{Hg}$ accumulation in lake sediment. Release of $\mathrm{Hg}$ from particles will cause $\mathrm{Hg}$ to build up in the water and increase its export downstream. Another process of great concern is methylation of $\mathrm{IHg}$ to $\mathrm{MeHg}$ because it leads to a dramatic increase in bioavailability. Methylation may also increase the mobility of $\mathrm{Hg}$ in anaerobic environments (Regnell et al. 1996; Bloom et al. 1999). Reduction to $\operatorname{Hg}(0)$ and volatilization has been shown to significantly reduce the net input of $\mathrm{Hg}$ to lakes (e.g., Poissant et al. 2000).

Lake stratification is known to increase net $\mathrm{MeHg}$ produc- 
tion and also to increase the recycling of $\mathrm{Hg}$ in the water column and at the sediment-water interface. Typically, anoxic conditions develop in hypolimnia of stratified lakes, which may or may not be accompanied by increased levels of free sulfide $\left(\mathrm{H}_{2} \mathrm{~S}\right.$ and $\left.\mathrm{HS}^{-}\right)$. It is widely recognized that $\mathrm{MeHg}$ is produced mainly under anoxic conditions and that the major $\mathrm{Hg}$ methylators are found within the group of sulfate-reducing bacteria (Compeau and Bartha 1985). However, sulfide generated by these bacteria is known to inhibit $\mathrm{Hg}$ methylation by rendering $\mathrm{Hg}$ less available for methylation (Berman and Bartha 1986; Benoit et al. 1999).

Hypolimnetic enrichment of total $\mathrm{Hg}(\mathrm{THg})$ and $\mathrm{MeHg}$ is a common phenomenon and several mechanisms explaining it have been suggested: $(i)$ reductive dissolution of iron and manganese oxides with which $\mathrm{Hg}(\mathrm{II})$ and $\mathrm{MeHg}$ are associated (e.g., Cossa et al. 1994; Jackson 1998), (ii) formation of water-soluble $\mathrm{Hg}$ (II)-sulfide complexes and $\mathrm{MeHgSH}$ (e.g., Wang and Driscoll 1995; Regnell et al. 1997), (iii) mineralization of settling biotic particles, leading to dissolved or colloidal forms of $\mathrm{Hg}$ (Hurley et al. 1991), (iv) sedimentation of dense layers of seston that have accumulated $\mathrm{Hg}$ in the upper water layers (Hurley et al. 1991), and (v) in situ methylation of IHg (Watras et al. 1995a).

The present study was designed primarily to shed light on the effect of stratification, anoxia, and sulfide on retention and recycling of $\mathrm{THg}$ and $\mathrm{MeHg}$ in two consecutive $\mathrm{Hg}$ polluted boreal lakes in a Swedish river system. In order to meet this goal, we followed seasonal variation in the levels of $\mathrm{THg}, \mathrm{MeHg}$, and various physicochemical variables in the water, settling matter, and surface sediment from May to December in 1996.

\section{Materials and methods}

\section{Lakes}

The study lakes, Övre Svartsjön and Nedre Svartsjön (referred to below as "the upper lake" and "the lower lake") are situated in southeastern Sweden. A small river (yearly average flow $0.9 \mathrm{~m}^{3} \cdot \mathrm{s}^{-1}$ ) passes through the lakes, the lower lake being immediately downstream of the upper lake (Fig. 1). The theoretical residence time of the water, based on the average yearly flow, was 4 days in the upper lake and 10 days in the lower lake. Upstream from the lakes, a paper mill is situated that released cellulose fibers, mostly from unbleached ground wood pulp, into the river until new treatment facilities were constructed in the early 1970s. Between 1940 and 1965 , the pulp was impregnated with phenyl mercury acetate to prevent slime growth. Because of the low stability of phenyl mercury (Jackson 1998), we thought that it was reasonable to assume that all phenyl mercury acetate had been converted to $\mathrm{IHg}$ and $\mathrm{MeHg}$.

The upper lake, being the first major sedimentation basin, has accumulated large amounts of cellulose fibers. According to a recent survey, it contains approximately 14400 t (dry) of sediment containing cellulose fibers showing variable degrees of degradation. In the lower lake, no cellulose fibers were found, but its bottom sediment may contain material originating from cellulose fiber. Basic limnological data for the two lakes are given in Table 1.

\section{Sampling strategy}

Water samples were collected monthly (May-December 1996) at the site of maximum depth in each lake. On all occasions, water was sampled from $0.5 \mathrm{~m}$ below the surface and $0.5 \mathrm{~m}$ above the bottom sediment. In July and August, water samples were collected
Fig. 1. Lakes of the present study. The location of the sampling stations and depth isopleths (m) are shown. The arrows indicate the direction of water flow. The inset map shows the location of the study lakes.

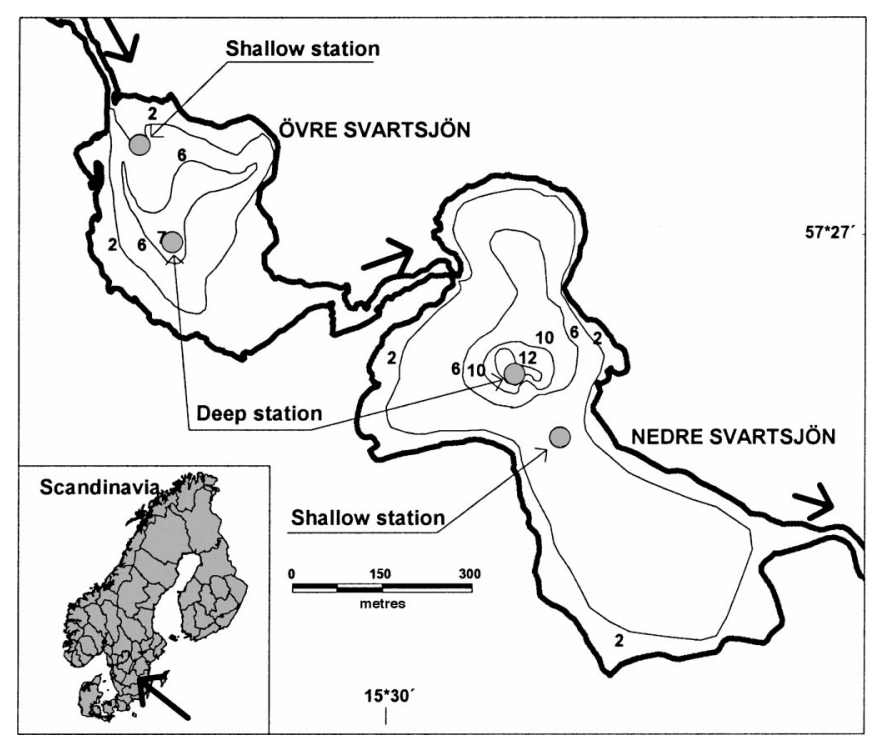

Table 1. Basic features of the two study lakes.

\begin{tabular}{lll}
\hline Variable & Upper lake & Lower lake \\
\hline Area $\left(\mathrm{km}^{2}\right)$ & 0.12 & 0.25 \\
Mean depth $(\mathrm{m})$ & 2.4 & 3.2 \\
Maximum depth $(\mathrm{m})$ & 7.2 & 12.1 \\
pH & $6.2-7.1$ & $6.5-7.1$ \\
Alkalinity $(\mathrm{mM})$ & $0.18-0.36$ & $0.19-0.36$ \\
Color $\left(\mathrm{mg} \mathrm{Pt} \cdot \mathrm{L}^{-1}\right)$ & $20-100$ & $15-100$ \\
Total N $(\mu \mathrm{M})$ & $20-41$ & $19-38$ \\
Total P $(\mu \mathrm{M})$ & $0.13-0.45$ & $0.13-0.45$ \\
\hline
\end{tabular}

Note: The concentration ranges are for epilimnetic water during 1996.

from three additional depths in the thermocline. In the lower lake, which was stratified longer, this was done also in September.

Surface sediment samples $(0-1 \mathrm{~cm})$ were collected from two stations in each lake, one at a shallow site where the sediment-water interface was always well oxygenated and the other at the site of maximum depth. Four or five sediment samples were taken from each station on each occasion. Locations of the sampling sites are shown in Fig. 1. In the fall of 1999, one core was taken at each station in the lower lake in order to determine the vertical distribution of $\mathrm{Hg}$ and other constituents in the sediment.

Sediment traps (Limnos OY, Finland), inner diameter $=62 \mathrm{~mm}$ and height $=400 \mathrm{~mm}$, were placed $1 \mathrm{~m}$ above the sediment-water interface in the vicinity of each of the four stations for sediment sampling. These were emptied monthly between June and December. No preservative was added to the traps.

\section{Sampling methods}

Water for all types of analyses was collected using a metal-free Ruttner sampler, which was rinsed with ultraclean $\mathrm{HNO}_{3}$ and MQ water before use. Teflon bottles $(120 \mathrm{~mL})$, filled with ultraclean MQ water and $0.5 \mathrm{~mL}$ of concentrated $\mathrm{HCl}$, were emptied and rinsed twice with the sample water before being completely filled with sample. Each Teflon bottle was then double bagged using plastic polyethylene bags and placed in a refrigerated box. To 
avoid contamination, plastic gloves were used during sampling. The samples were immediately transported to the laboratory. There, prior to storage at $6-9^{\circ} \mathrm{C}, 0.6 \mathrm{~mL}$ of $\mathrm{HCl}$ was added to each sample.

Sediment samples were obtained with a corer of our own design equipped with plastic liners. Only the top $0-1 \mathrm{~cm}$ of the sediment was transferred to plastic jars. These were double bagged and placed in a refrigerated box and then stored frozen until analysis. The sediment trap material was handled in a similar manner.

\section{Analytical procedures}

$\mathrm{THg}$ in water was quantified using a double-amalgamation technique and atomic fluorescence detection. Sediment samples were wet oxidized in Teflon containers to which concentrated $\mathrm{HNO}_{3}$ was added. The Teflon containers were placed in an autoclave $\left(123^{\circ} \mathrm{C}\right)$ for $1 \mathrm{~h}$. The samples were then transferred to a reaction vessel to which $\mathrm{SnCl}_{2}$ was added to convert all $\mathrm{Hg}$ to elemental $\mathrm{Hg}$. A coldvapor atomic absorption spectrophotometer (LDC mercury monitor) was used for quantification. See Table 2 for detection limits and precision of measurements.

$\mathrm{MeHg}$ was determined by the method of Bloom (1989). However, instead of extraction, the initial cleanup and preconcentration step was distillation (Horvat et al. 1988). In order to quantify $\mathrm{MeHg}$ in sediment samples, all $\mathrm{MeHg}$ was transferred to water using a similar distillation procedure as for water samples. Artifact formation of $\mathrm{MeHg}$ during distillation has been demonstrated. This could be significant for sediment samples with $<1 \%$ of $\mathrm{THg}$ as $\mathrm{MeHg}$ (Bloom et al. 1997). Since the proportion of $\mathrm{THg}$ present as $\mathrm{MeHg}$ in the majority of our sediment samples was well above $1 \%$, we are confident that any artifact $\mathrm{MeHg}$ could be safely neglected. See Table 2 for detection limits and precision of measurements. A more thorough description of the analytical procedures for the determination of $\mathrm{THg}$ and $\mathrm{MeHg}$ in water and $\mathrm{MeHg}$ in sediment is given in Regnell et al. (1997).

Total $\mathrm{Fe}$ and $\mathrm{Mn}$ were determined in water samples that were acidified with $\mathrm{HNO}_{3}$ using an ICP-ES instrument (Perkin Elmer, plasma II emission spectrometer). Total Fe, Mn, P, and $\mathrm{S}$ were quantified in lyophilized sediment samples after wet oxidation using the same instrument (see Regnell et al. 1997).

Total organic carbon (TOC) in water was determined using a carbon analyzer (Shimadzu, TOC-500). Particulate organic carbon (POC) was estimated from the concentration of suspended particulate matter (SPM), the ignition loss of SPM, and the relationship between ignition loss and total $\mathrm{C}$ in the surface sediment below (ignition loss $=K \times$ total $\mathrm{C}$, where $K=2.0$ and 2.1 in the upper and lower lake, respectively). Dissolved organic carbon (DOC) was calculated by subtraction. The total $\mathrm{C}$ content of the sediment was determined using a carbon analyzer for solid samples (LECO). Since both study lakes are softwater lakes (low alkalinities), it can be assumed that total $\mathrm{C}$ represented TOC in the sediment.

Sulfide in water samples was measured colorimetrically using the methylene blue method (Fonselius 1983). The samples were stabilized in the field by adding solutions of zinc acetate and $\mathrm{NaOH}$. Water temperature and dissolved oxygen were measured directly in the field with a temperature-oxygen probe (YSI model 58).

\section{Data analysis}

To study covariation between two variables, Pearson's productmoment correlation coefficients $(r)$ and associated significant probabilities $(P)$ were computed for untransformed data (log transformation resulted in virtually the same values). For each correlation matrix, the $P$ values of the correlation coefficients were corrected using a sequential Bonferroni test (Sokal and Rohlf 1995). When pairwise relationships between sediment variables were investigated, mean values from each sampling date $(n=4-5)$ were used. The correlation coefficients thus reflected temporal rather than small-scale spatial relationships between the variables at each station. To further illustrate covariation between sediment variables, principal components analysis (PCA) was performed. All variables were standardized prior to performing the PCA. Because all the individual sediment samples at one station were used in this calculation, the PCAs reflected not only temporal variation but also small-scale spatial variation at the four sampling stations. Spatial variation would result from the fact that samples were taken at least a few inches apart on the same sampling occasion and probably metres apart between sampling occasions.

\section{Results and discussion}

Enrichment of $\mathrm{MeHg}$ and $\mathrm{IHg}$ in the hypolimnetic water

In both lakes, $[\mathrm{MeHg}]$ and $[\mathrm{IHg}]$ increased in the anoxic hypolimnion during summer stratification. A constant rate of release from the bottom sediment and (or) settling matter does not conform to the fact that the lakes were stratified long before $[\mathrm{MeHg}]$ and $[\mathrm{IHg}]$ started to rise in the hypolimnion (cf. Figs. 2 and 3). Moreover, in both lakes, the buildup of $\mathrm{MeHg}$ in the surficial sediment preceded that in the overlying water. The fact that [total Fe] and [total Mn] peaked simultaneously with [MeHg] and $[\mathrm{IHg}]$ in the hypolimnetic water of both lakes indicated that release of $\mathrm{Hg}$ occurred mainly at low redox potentials (Fig. 3).

Hydrous ferric and manganese oxides (HFO and HMO) have high capacity for binding both $\mathrm{MeHg}$ and $\mathrm{Hg}$ (II) (Cossa et al. 1994; Gagnon and Fisher 1997). The increase in [total $\mathrm{Fe}$ ] and [total $\mathrm{Mn}$ ] in the hypolimnion was most likely the result of reductive dissolution of HFO and HMO occurring both in the sediment and on suspended particles in the hypolimnion. The simultaneous increase in hypolimnetic [IHg] and [MeHg] could be explained by release of $\mathrm{Hg}(\mathrm{II})$ and $\mathrm{MeHg}$ in conjunction with reductive dissolution of $\mathrm{HFO}$ and HMO.

In the hypolimnion of the upper lake, the increase in $[\mathrm{IHg}]$ started approximately a month later than the increase in $[\mathrm{MeHg}$ ], [total Fe], and [total Mn] (Fig. 3). Possibly, almost all $\mathrm{Hg}$ released from particulate matter was methylated during the initial phase of anoxia in the upper lake, after which methylation was inhibited by high sulfide levels, allowing a significant buildup of $\mathrm{IHg}$. In the lower lake, in which methylation rates were much lower, [IHg] increased simultaneously with [MeHg] (Fig. 3).

In both lakes, the correlation between [MeHg] and [total $\mathrm{Fe}]$ in the hypolimnetic water was strong and highly significant statistically ( $z$ test, Bonferroni correction: $P<0.01$ ), whereas that between [IHg] and [total Fe] was not (Table 3). This indicated that the redox cycle of Fe had a stronger influence on $[\mathrm{MeHg}]$ than on [IHg]. Bloom et al. (1999) found the highest $[\mathrm{MeHg}]$ in marine sediment pore water at the point of maximum [total Fe], whereas the solubility of $\mathrm{IHg}$ was unrelated to changes in [total Fe] and [total Mn]. They concluded that the mobility of $\mathrm{MeHg}$ was controlled by metal oxide solubilization and that the mobility of $\mathrm{IHg}$ was controlled by formation of soluble sulfide or organic complexes. We believe that, in addition to the direct association of $\mathrm{MeHg}$ with $\mathrm{HFO}$, a positive relationship between [total $\mathrm{Fe}]$ and $[\mathrm{MeHg}]$ in the hypolimnetic water could be explained by the fact that reductive dissolution of HFO and production of $\mathrm{MeHg}$ are both the result of anaerobic microbial activity. Furthermore, both the solubility of $\mathrm{Fe}(\mathrm{II})$ and the production of $\mathrm{MeHg}$ are reduced by high sulfide levels. 
Table 2. Data on the analytical quality of the $\mathrm{THg}$ and $\mathrm{MeHg}$ measurements in the present study.

\begin{tabular}{|c|c|c|c|c|c|c|}
\hline \multicolumn{7}{|c|}{ Detection limit ${ }^{a}$} \\
\hline \multicolumn{2}{|c|}{ Water $(\mathrm{pM})$} & \multicolumn{2}{|c|}{ Sediment $\left(\mathrm{pmol} \cdot \mathrm{g} \mathrm{dry}^{-1}\right)$} & & & \\
\hline $\mathrm{THg}$ & $\mathrm{MeHg}$ & $\mathrm{THg}$ & $\mathrm{MeHg}$ & & & \\
\hline \multirow[t]{3}{*}{0.25} & 0.1 & 10 & 0.05 & & & \\
\hline & & & Precision & & & \\
\hline & & & $\mathrm{THg}(\mu \mathrm{g} \mathrm{H}$ & $\left(r y^{-1}\right)$ & $\mathrm{MeHg}$ (ng & dry $\left.^{-1}\right)$ \\
\hline \multicolumn{3}{|c|}{ Reference material } & Certified & Obtained & Certified & Obtained \\
\hline \multicolumn{5}{|c|}{ IAEA-356 (marine sediment) } & $5.46 \pm 0.38$ & $5.60 \pm 0.36^{b}$ \\
\hline \multicolumn{3}{|c|}{ CRM 320, BCR (river sediment) } & $1.03 \pm 0.13$ & $1.02 \pm 0.07^{c}$ & & \\
\hline
\end{tabular}

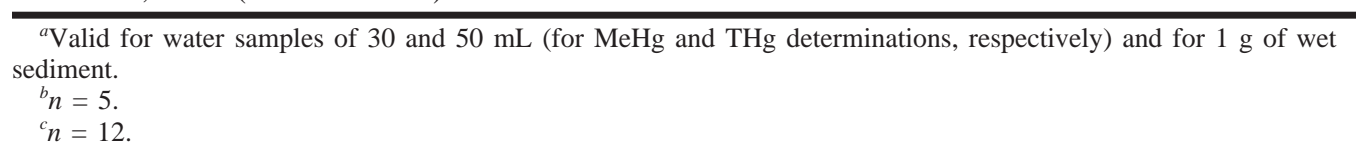

Fig. 2. Temporal variation in the extension of the metalimnion (thermocline), temperature in the surface and bottom water, and depth below which oxygen was <1 ppm during 1996 in the (a) upper lake and $(b)$ lower lake. $\square, 0.5 \mathrm{~m}$ below the surface; $\checkmark$, at maximal water depth. a)

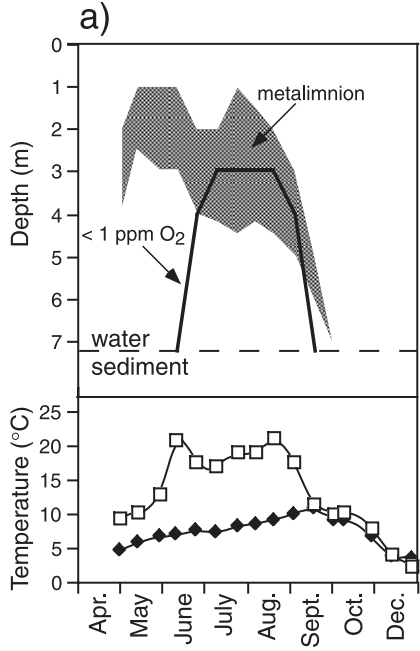

b)

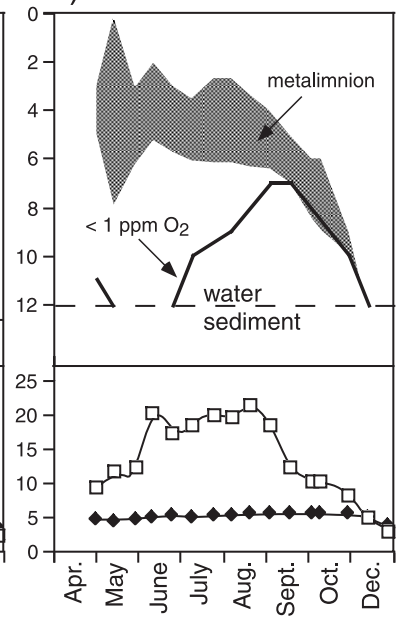

Sulfate-reducing bacteria, known to produce $\mathrm{MeHg}$ when free sulfide levels are low to moderate (Compeau and Bartha 1985, 1987), inhibit $\mathrm{Hg}$ methylation as well as remove $\mathrm{Fe}$ (II) from solution ( $\mathrm{FeS}(\mathrm{s})$ formation) as a result of their production of sulfide.

For the upper lake, it is clear that the hypolimnetic buildup of $\mathrm{Mn}$ started earlier than that of $\mathrm{MeHg}$ (Figs. $3 a$ and $3 e$ ), but this should not be taken as evidence that HMO is a poor scavenger of MeHg. While $\mathrm{Mn}(\mathrm{II})$ is known to be able to diffuse through oxic sediment layers (Davison et al. 1982), it seems probable that any $\mathrm{MeHg}$ released in conjunction with reductive dissolution of HMO would become trapped by oxides still remaining at the sediment-water interface. In addition, since most of the hypolimnetic $\mathrm{MeHg}$ probably was a result of in situ production rather than of release of $\mathrm{MeHg}$ from the sediment (see below), reductive dissolution of manganese oxide seemed to have started at higher redox potentials than $\mathrm{Hg}$ methylation.

Besides scavenging oxides, organic particles as well as dissolved organic complexing agents will affect the mobility of $\mathrm{Hg}$. In the hypolimnion of the lower lake, in which sulfide could not be detected during the study period, [IHg] and [MeHg] peaked simultaneously with [DOC] and showed seasonal variation similar to that of [DOC] also for the rest of the study period (Figs. 3 and 4; Table 3). [DOC], in turn, peaked simultaneously with and showed a seasonal variation similar to that of [total Fe] and [total Mn] (Figs. 3 and 4). These results are in line with the earlier stated assumption that $\mathrm{Hg}(\mathrm{II})$ and $\mathrm{MeHg}$ are bound to $\mathrm{HFO}$ and $\mathrm{HMO}$ via organic ligands (Regnell et al. 1997). This is likely the case because virtually all filter-passing $\mathrm{Hg}$ (II) and $\mathrm{MeHg}$ in nonsulfidic water is bound to dissolved or colloidal organic matter (Stordal et al. 1996; Hintelmann et al. 1997) and because oxides are efficient scavengers of dissolved and colloidal organic compounds (Tipping and Woof 1983). However, as discussed by Tipping and Woof (1983), organic matter can accumulate in hypolimnia not only as a result of dissolution of oxides but also as a result of anaerobic decomposition of particulate organic matter resulting in dissolved and colloidal forms. A simultaneous buildup of total Fe could be explained by microbially mediated reduction of $\mathrm{Fe}$ (III) to more soluble Fe(II). Similarly, rather than being a result of dissolution of $\mathrm{HFO}$ and $\mathrm{HMO}$, the hypolimnetic buildup of $\mathrm{Hg}$ could have been the result of decomposition of particulate organic matter to which it was bound. In line with this interpretation of the simultaneous buildup of $\mathrm{THg}$, total $\mathrm{Fe}$, and total Mn, Hurley et al. (1991) concluded that mineralization of settling particles of biological origin explained the hypolimnetic enrichment of $\mathrm{THg}$ in a Wisconsin seepage lake. Not knowing the composition of the particles carrying most of the $\mathrm{Hg}$, we cannot tell whether organic matter decomposition was the primary cause of the hypolimnetic $\mathrm{Hg}$ enrichment or not. In any case, we believe that the redox cycles of $\mathrm{Fe}$ and $\mathrm{Mn}$ had a major effect on the amount of dissolved and colloidal $\mathrm{Hg}$ because any such $\mathrm{Hg}$ formed during organic matter degradation could be scavenged by HFO and HMO.

Even if not mineralized, dense layers of settling matter that have accumulated $\mathrm{Hg}$, e.g., decaying phytoplankton, could give rise to what would appear as a hypolimnetic $\mathrm{THg}$ enrichment of short duration before ending up in the sediment. For our study lakes, a hypolimnetic enrichment of $\mathrm{THg}$ due high concentrations of settling (or resuspended) particles with which $\mathrm{Hg}$ was associated is not in line with our observation that [POC] and [SPM] did not increase simultaneously with [THg] (Fig. 4). 
Fig. 3. Temporal variation in $[\mathrm{MeHg}],[\mathrm{THg}],[\mathrm{IHg}]$, and concentrations of ancillary constituents in the surface sediment $(0-1 \mathrm{~cm})$ and hypolimnetic water during 1996 in the $(a-f)$ upper lake and $(g-l)$ lower lake. The samples were taken at the deep stations. Bars represent $\pm 1 \mathrm{SD}(n=4$ or 5$)$. The values for water are based on single samples. $\boldsymbol{\square}$, sediment $(0-1 \mathrm{~cm})$; $\square$, water $(0.5 \mathrm{~m}$ above the sediment).

\section{The upper lake}
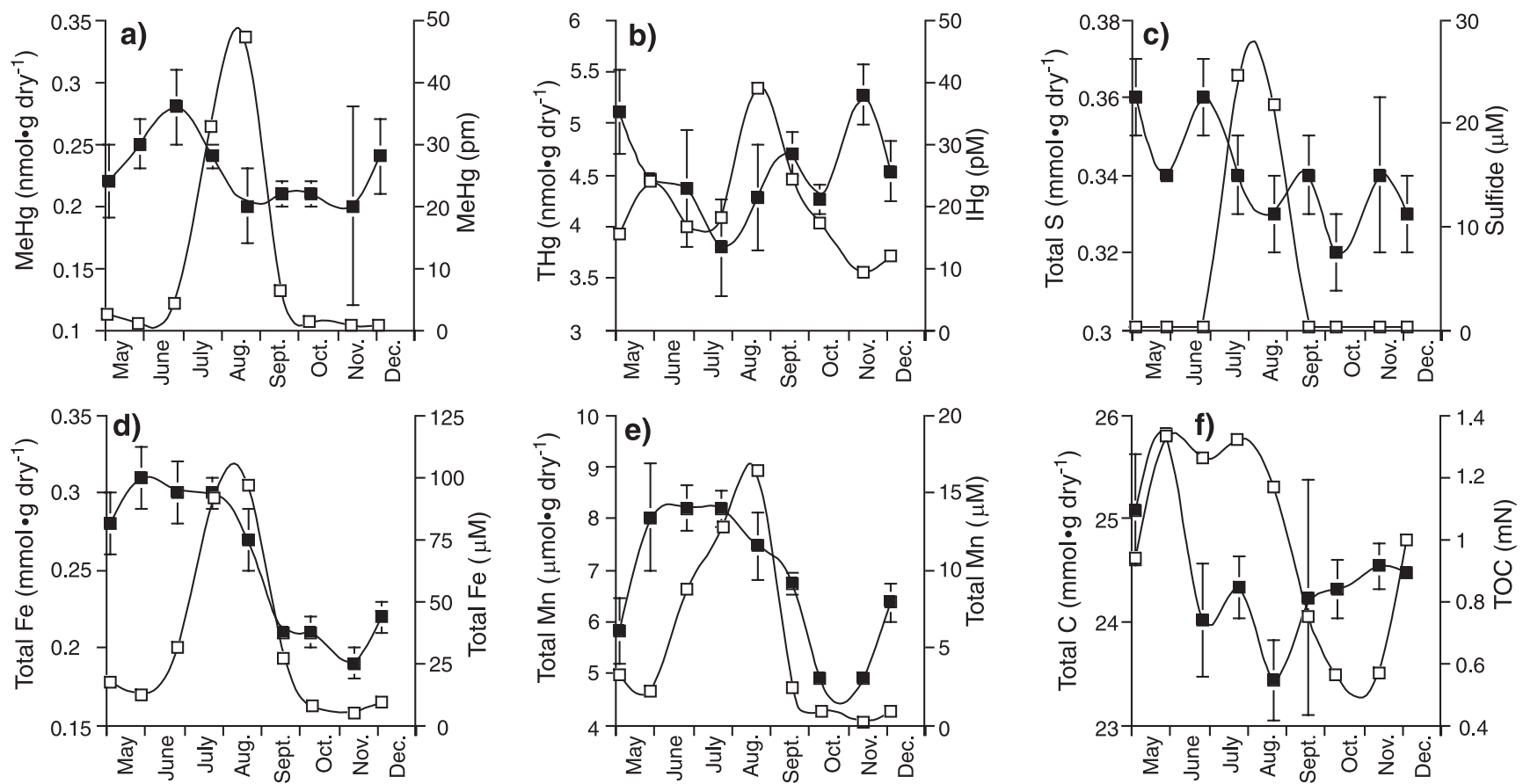

\section{The lower lake}
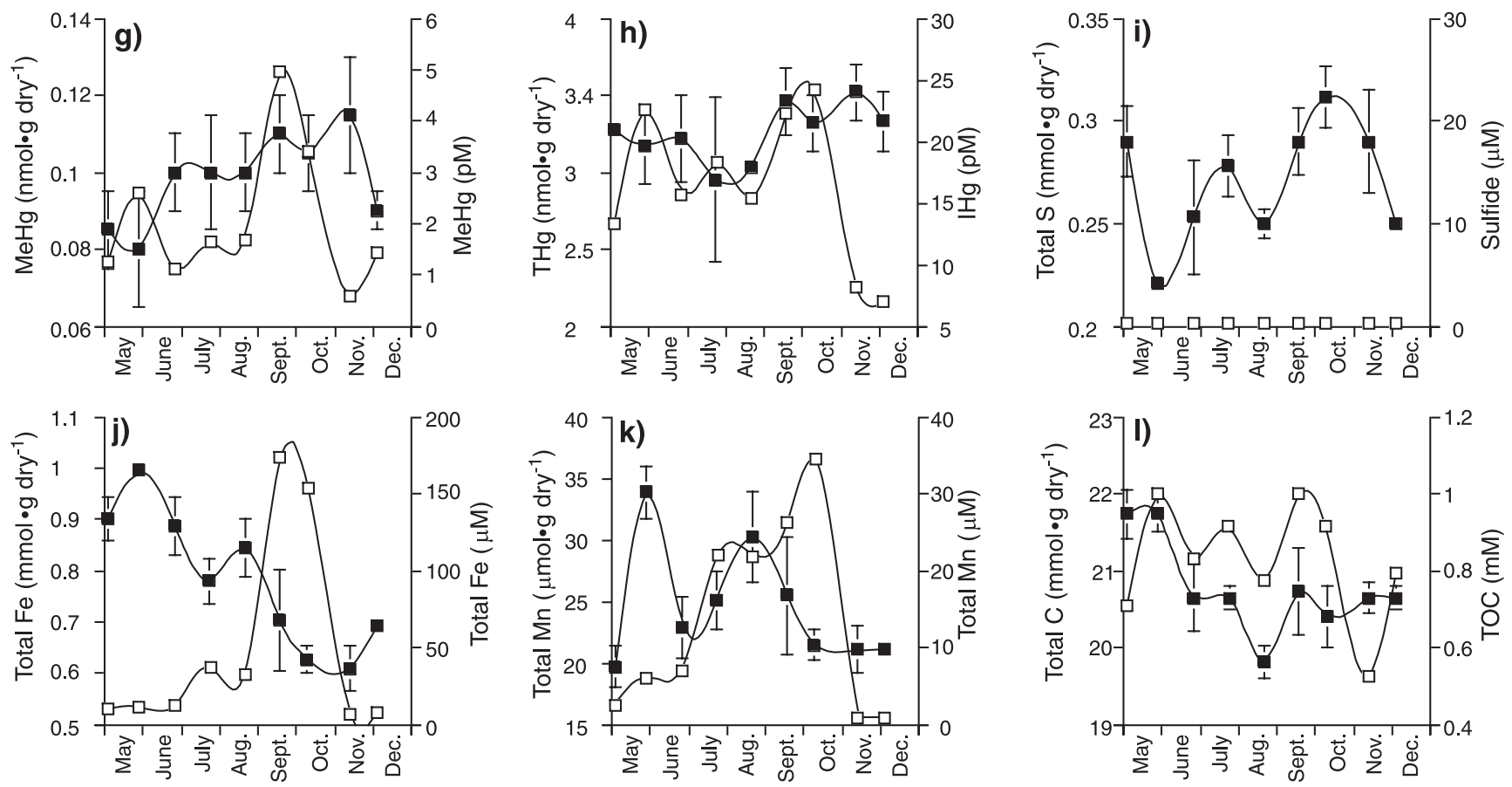

Yet another explanation for hypolimnetic $\mathrm{Hg}$ enrichment is that $\mathrm{Hg}(\mathrm{II})$ and $\mathrm{MeHg}$ form soluble complexes with bisulfide and (or) polysulfide or that $\mathrm{Hg}$ (II) forms colloidal HgS (Wang and Driscoll 1995; Hintelmann et al. 1997; Paquette and Helz 1997). However, precipitation of $\mathrm{Hg}(\mathrm{II})$ as
$\mathrm{HgS}(\mathrm{s})$ or its coprecipitation with $\mathrm{FeS}$ may also occur, depending on several factors such as the free sulfide concentration, $\mathrm{pH}, \mathrm{Fe}$ (II) concentration, and the level and quality of dissolved organic matter (Dyrssen and Wedborg 1991; Ravichandran et al. 1999). The fact that sulfide levels were high 
Fig. 4. Temporal variation in $[\mathrm{THg}],[\mathrm{DOC}],[\mathrm{POC}]$, and $[\mathrm{SPM}]$ in the hypolimnetic water during 1996 in the (a) upper lake and (b) lower lake. The values are based on single samples.

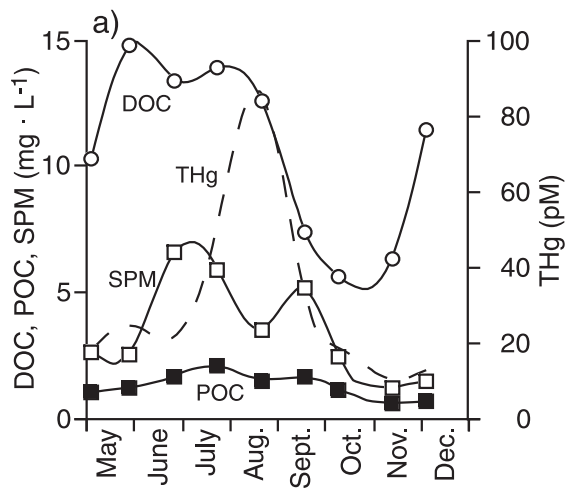

Table 3. Pairwise correlation $(r)$ with the variables indicated.

\begin{tabular}{lll}
\hline Variables & Upper lake & Lower lake \\
\hline $\mathrm{MeHg}$ vs. TOC & 0.45 & 0.75 \\
$\mathrm{MeHg}$ vs. POC & 0.58 & 0.56 \\
$\mathrm{MeHg}$ vs. DOC & 0.40 & 0.60 \\
$\mathrm{MeHg}$ vs. SPM & 0.36 & 0.56 \\
$\mathrm{MeHg}$ vs. total Fe & $0.97 * * *$ & $0.90^{* *}$ \\
$\mathrm{MeHg}$ vs. total $\mathrm{Mn}$ & $0.92^{* * *}$ & 0.69 \\
$\mathrm{MeHg}$ vs. IHg & 0.73 & 0.76 \\
$\mathrm{IHg}$ vs. TOC & 0.37 & $0.82^{*}$ \\
$\mathrm{IHg}$ vs. POC & 0.48 & 0.62 \\
$\mathrm{IHg}$ vs. DOC & 0.32 & 0.66 \\
$\mathrm{IHg}$ vs. SPM & 0.26 & 0.64 \\
$\mathrm{IHg}$ vs. total Fe & 0.65 & 0.68 \\
$\mathrm{IHg}$ vs. total $\mathrm{Mn}$ & 0.66 & 0.74 \\
\hline
\end{tabular}

Note: These were measured on nine occasions at approximately monthly intervals between May and December 1996 in the hypolimnetic water of the upper lake and lower lake. ${ }^{*} P<0.05 ; * * P<0.01 ; * * * P<0.001$

when $[\mathrm{IHg}]$ and $[\mathrm{MeHg}]$ peaked in the hypolimnion of the upper lake indicates that the solubility of $\mathrm{Hg}$ increased instead of decreasing in the presence of sulfide (Fig. 3). Furthermore, the lack of a clear relationship between $\mathrm{Hg}$ and DOC (Figs. 3 and 4; Table 3) suggests that $\mathrm{Hg}$ formed complexes with sulfide rather than with DOC during the buildup of $\mathrm{Hg}$ in the hypolimnion. The sulfide levels that we measured in the hypolimnion of the upper lake fell within the range that Benoit et al. (1999) stated would lead to sulfide complexation of $\mathrm{Hg}$ (II) and to negligible amounts of $\mathrm{Hg}$ (II)DOC complexes. Also, using the equilibrium calculations provided by Hintelmann et al. (1997), sulfide would outcompete DOC in the complexation of $\mathrm{MeHg}$.

High [THg] in sulfidic hypolimnetic water has been observed by others (e.g., Wang and Driscoll 1995). Furthermore, a positive correlation between sulfide and [THg] has been found in estuarine and marine pore water (e.g., Bloom et al. 1999).

\section{Levels of MeHg and THg in the epilimnetic and hypolimnetic surface sediment}

It may seem surprising that sediment $\mathrm{MeHg}$ levels

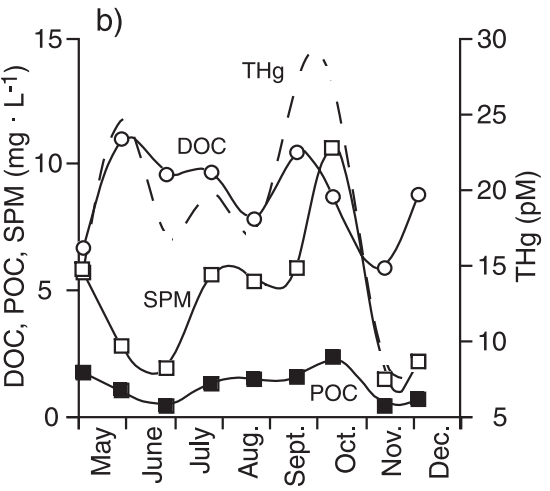

$\left([\mathrm{MeHg}]_{\mathrm{SE}}\right)$ were consistently higher at the shallow station than at the deep station in the upper lake, while the situation was the opposite in the lower lake (Figs. $5 a$ and $5 b$ ). Several independent observations suggested that free sulfide had a significant influence on $[\mathrm{MeHg}]_{\mathrm{SE}: 0-1 \mathrm{~cm}}$ and was one of the variables explaining the fact that $\mathrm{MeHg}$ was differently distributed in the two lakes.

At the shallow station in the upper lake, where dissolved oxygen was always $>8 \mathrm{ppm}$ in the water above the sediment surface, $[\mathrm{MeHg}]_{\mathrm{SE}}: 0-1 \mathrm{~cm}$ peaked in August, whereas at the deep station where sulfide was present in the bottom water, $[\mathrm{MeHg}]_{\mathrm{SE}}$ : $0-1 \mathrm{~cm}$ showed a steady decline during July-August (Fig. 5a). This decline could be explained by release of $\mathrm{MeHg}$ to the water, in line with the fact that [MeHg] increased in the overlying water (Fig. $3 a$ ).

As stated, release of $\mathrm{MeHg}$ from sediment can be a result of depletion of $\mathrm{MeHg}$-scavenging $\mathrm{HFO}$ and HMO. The presence of free sulfide indicated that sulfide-reactive $\mathrm{HFO}$ and HMO had indeed become depleted in the sediment at the deep station in the upper lake (Fig. $3 c$ ). It is also possible that the presence of free sulfide had a direct influence on the water solubility of $\mathrm{MeHg}$ through the formation of $\mathrm{MeHgSH}$. Using thermodynamic data, Davies-Colley et al. (1985) concluded that metals that form soluble sulfide complexes could be released from anoxic sediment when sulfide-reactive Fe is depleted and free sulfide becomes available for complexation. If this interaction between sulfide-reactive $\mathrm{Fe}$ and sulfide affects $\mathrm{MeHg}$ in a similar manner, $\mathrm{HFO}$ might control $\mathrm{MeHg}$ release not only by its ability to bind $\mathrm{MeHg}$ but also by its ability to bind sulfide, thereby counteracting the formation of $\mathrm{MeHgSH}$ (or any other $\mathrm{MeHg}$ sulfide/polysulfide species). Note that the decrease in $[\mathrm{MeHg}]_{\mathrm{SE}}: 0-1 \mathrm{~cm}$ and [total $\mathrm{S}]_{\mathrm{SE}: 0-1 \mathrm{~cm}}$ coincided and that both [MeHg] and [sulfide] increased in the overlying water when this occurred (Figs. $3 a$ and $3 c$ ). Given that $\mathrm{IHg}$ forms complexes with sulfide, its solubility would also be affected by the ability of Fe to scavenge free sulfide.

The decline in $[\mathrm{MeHg}]_{\mathrm{SE}: 0-1 \mathrm{~cm}}$ at the deep station may also have been the result of demethylation. However, given the rapid increase in $[\mathrm{MeHg}]$ in the water $0.5 \mathrm{~m}$ above the sediment, it seems unlikely that demethylation should be the sole cause (Fig. 3a). A net loss of $\mathrm{MeHg}$ will result when its rate of formation is lower than its rate of decomposition. When $\left[\mathrm{HS}^{-}\right]$increases, the production of $\mathrm{MeHg}$ decreases or even stops (Berman and Bartha 1986; Benoit et al. 1999). 
Fig. 5. Temporal variation in $[\mathrm{MeHg}],[\mathrm{HgT}]$, [total $\mathrm{Fe}$ ], [total $\mathrm{Mn}$ ], and [total $\mathrm{C}$ ] in the surface sediment $(0-1 \mathrm{~cm})$ at the deep station (ם) and shallow station $(\square)$ during 1996 in the $(a, c, e, g$, and $i)$ upper lake and $(b, d, f, h$, and $j)$ lower lake. Bars represent \pm 1 SD $(n=4$ or 5$)$.

The upper lake
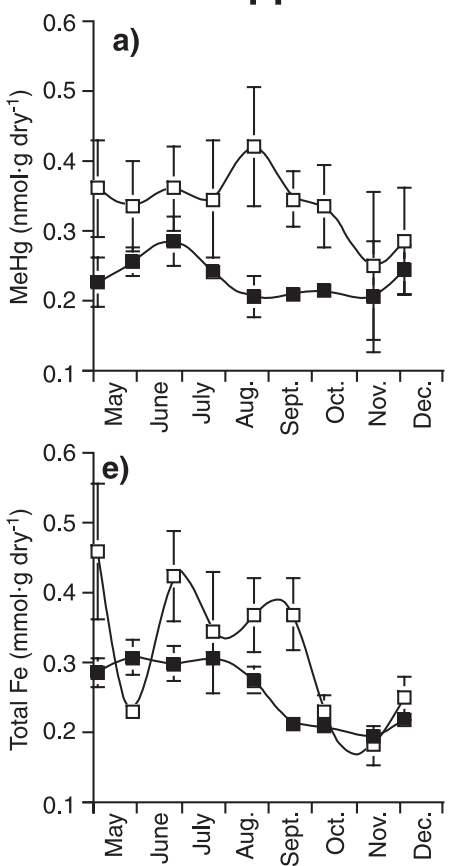

The lower lake
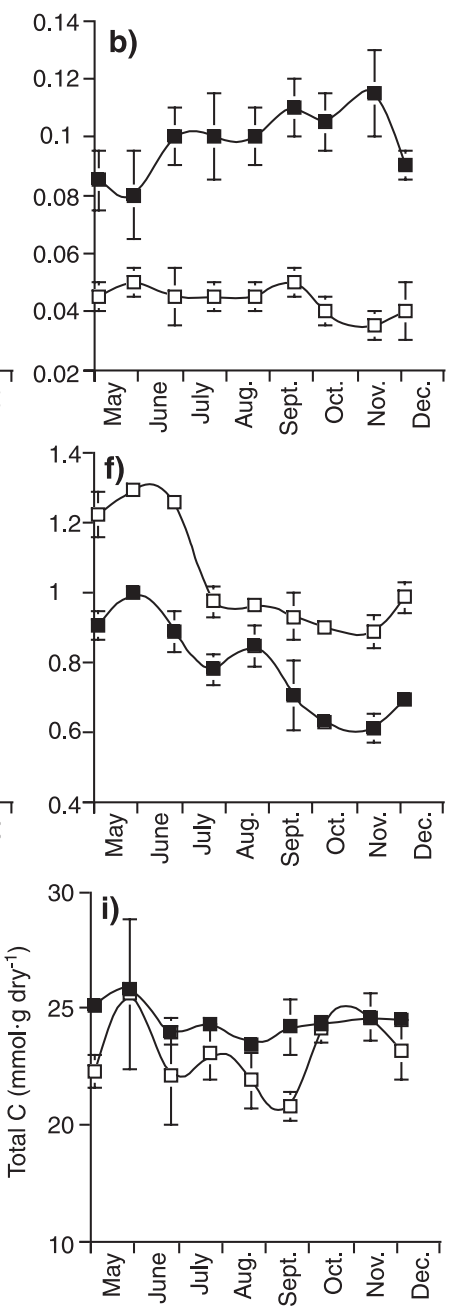

Thus, at high sulfide levels, even a slow rate of decomposition could result in declining $[\mathrm{MeHg}]_{\mathrm{SE}}$. Hintelmann et al. (2000) showed by using stable $\mathrm{Hg}$ isotopes that ambient $\mathrm{MeHg}$ in anoxic sediment slurries had a half-life of only 1.8 days. However, they found that sulfide additions totally inhibited $\mathrm{MeHg}$ loss. This seemed to contradict the earlier finding that addition of sulfide can convert $\mathrm{MeHg}$ to dimethyl mercury (DMeHg) (Wallschläger et al. 1995). According to Craig and Moreton (1984), the reaction sequence for this conversion is $2 \mathrm{MeHg}^{+}+\mathrm{S}^{2-}=(\mathrm{MeHg})_{2} \mathrm{~S}=\mathrm{HgS}+$ $\mathrm{DMeHg}$, where the last step occurs upon exposure to light. Thus, the stability of $\mathrm{MeHg}$ in sulfide-rich sediment remains uncertain.

The decrease in $[\mathrm{MeHg}]_{\text {SE: } 0-1 \mathrm{~cm}}$ at the shallow station in the fall could have followed changes in the microbial activity, resulting in demethylation exceeding methylation (Fig. 5a). Bodaly et al. (1993) found that the methylation to demethylation ratio in lake sediment decreased with decreasing temperature. Possibly, low temperatures are less disfavorable to demethylating organisms than to methylating ones. It is also possible that demethylation is partly an abiotic process

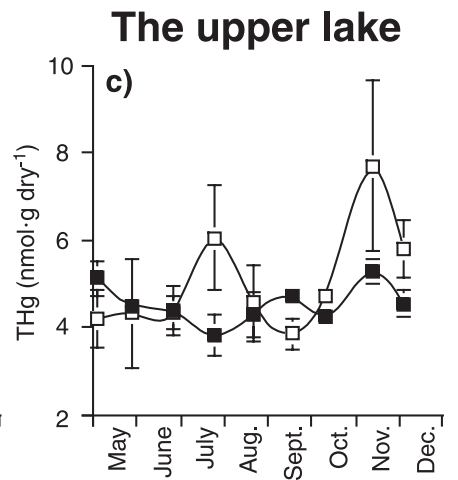

\section{The lower lake}
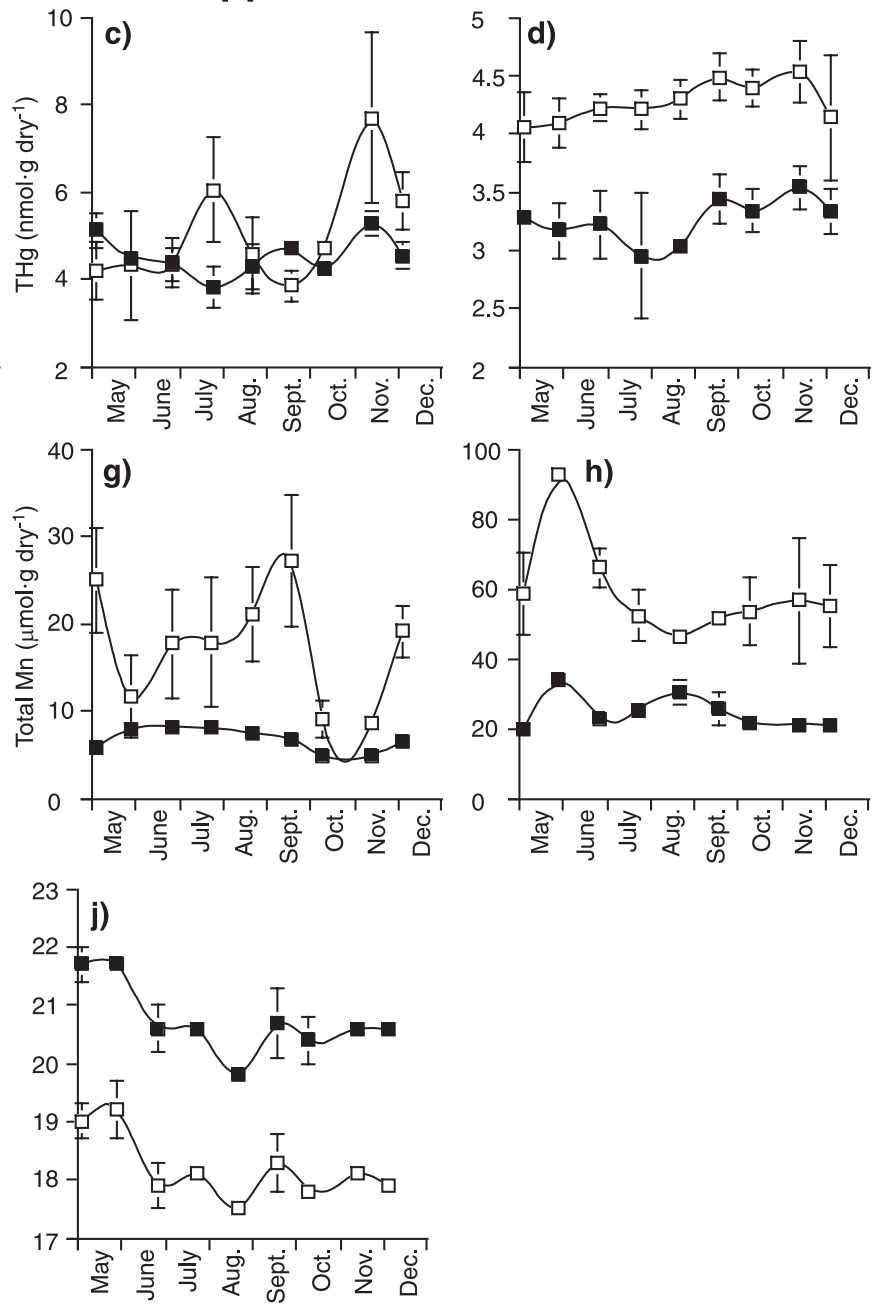

(Suda et al. 1991) and hence that it is less depressed at low temperatures than methylation. In the lower lake at the deep station, there was no decline in $[\mathrm{MeHg}]_{\text {SE: } 0-1 \mathrm{~cm}}$ during summer stratification (Fig. $5 b$ ). Instead, $[\mathrm{MeHg}]_{\mathrm{SE}: 0-1 \mathrm{~cm}}$ increased throughout this period, probably because invariably low sulfide levels in combination with anoxic conditions at the hypolimnetic sediment-water interface favored $\mathrm{Hg}$ methylation and millitated against mobilization of $\mathrm{MeHg}$ from the sediment.

At the shallow station, low $[\mathrm{MeHg}]_{\mathrm{SE}}$ 0-1 cm (Fig. 5b) probably resulted from low net methylation rates. Cellulose fibers, which have been shown to stimulate $\mathrm{MeHg}$ production (Regnell et al. 1996) and which probably stimulated $\mathrm{MeHg}$ production in the sediment at the shallow station in the upper lake, were not present in the sediment at this station.

$\mathrm{THg}$ showed a distribution opposite to that of $\mathrm{MeHg}$ in the lower lake, with consistently higher $[\mathrm{THg}]_{\mathrm{SE}: 0-1 \mathrm{~cm}}$ at the shallow station than at the deep station (Figs. $5 b$ and $5 d$ ). Because of the high affinity of $\mathrm{Hg}$ for fine organic-rich particles, one would expect sediment focusing to result in higher 
Fig. 6. Stratigraphy of [THg] in the sediment of the lower lake as measured on two sediment cores collected in the fall of 1999 . $\diamond$, deep station; $\diamond$, shallow station.

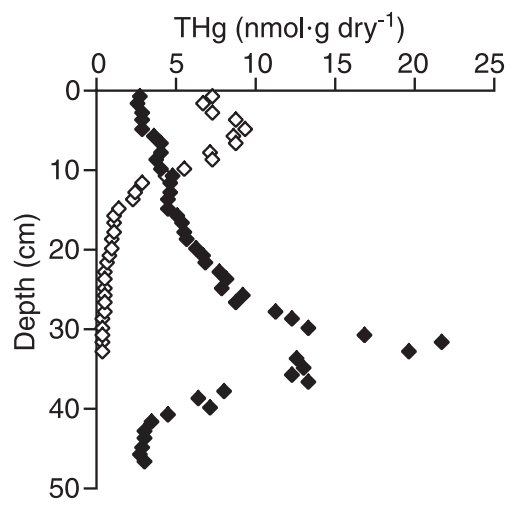

$[\mathrm{THg}]_{\text {SE: } 0-1 \mathrm{~cm}}$ in hypolimnetic than in epilimnetic sediment. Notably, [total $\mathrm{C}]_{\mathrm{SE}}: 0-1 \mathrm{~cm}$ was higher at the deep station than at the shallow station, indicating that organic matter was indeed subjected to focusing (Fig. $5 j$ ). The difference in [total C $]_{\text {SE: } 0-1 \mathrm{~cm}}$ did not seem to be an effect mainly of different organic matter degradation because [total C] $]_{\mathrm{SE}: 0-1 \mathrm{~cm}}$ decreased at similar rates at the two stations during summer (Fig. 5j).

It is evident from the $[\mathrm{THg}]_{\mathrm{SE}}$ depth profiles in the sediment cores sampled in the fall of 1999 that the major $\mathrm{Hg}$ pollution that occurred between 1940 and 1965 still had a strong effect on $[\mathrm{THg}]_{\mathrm{SE}: 0-1 \mathrm{~cm}}$ at the shallow station. At the deep station, the effect of this pollution on $[\mathrm{THg}]_{\mathrm{SE}}$ : $0-1 \mathrm{~cm}$ was much less because of a much higher sediment burial rate (Fig. 6). Thus, for lakes in which $\mathrm{Hg}$ pollution has stopped, sediment focusing could lead to higher [THg] in surface sediment at shallow sites than at deep sites. Of course, bioturbation rates may also affect the rate of burial of old pollution.

Looking at the temporal variation during summer stratification, it is evident that $[\mathrm{THg}]_{\mathrm{SE}: 0-1 \mathrm{~cm}}$ kept increasing at the shallow station while decreasing at the deep station (Fig. $5 d$ ). This indicated that retention and (or) incorporation of $\mathrm{THg}$ was higher at the shallow station, in line with the fact that $\mathrm{Hg}$ seemed to be released from particulate matter in conjunction with anaerobic conditions (Fig. 3). Thus, a higher retention of $\mathrm{Hg}$ could have contributed to the fact that $[\mathrm{THg}]_{\text {SE: } 0-1 \mathrm{~cm}}$ was higher at the shallow station than at the deep station.

\section{Relationships between THg, MeHg, and other constituents in the sediment}

Correlation analysis did not reveal any statistically significant $(P<0.05)$ temporal covariation between either THg or $\mathrm{MeHg}$ and the other sediment variables at any of the four stations, but the statistical power was low because of the high number of comparisons tested in each matrix $(n=11)$ and because sampling was restricted to nine occasions. We do not present these data because the pairwise relationships between the sediment variables were well reflected by the PCA plots (Fig. 7). In the PCAs, individual values instead of mean values were used. Thus, small-scale spatial variation was included in the calculation. However, the PCA plots
Fig. 7. Plots based on PC models, the variables being those indicated in the figure and the objects being the sediment samples ( 0 $1 \mathrm{~cm})(n=41$ or 42$)$ taken at the (a) upper lake deep station, (b) upper lake shallow station, (c) lower lake deep station, and (d) lower lake shallow station. The samples were taken on nine different occasions (four or five replicate samples on each occasion) at approximately monthly intervals during 1996. All variables were standarized $(\mathrm{SD}=1)$ prior to performing the PCA. The variance explained by each PC, expressed as a percentage of total variance, is given in parentheses. The large cross indicates the origin.
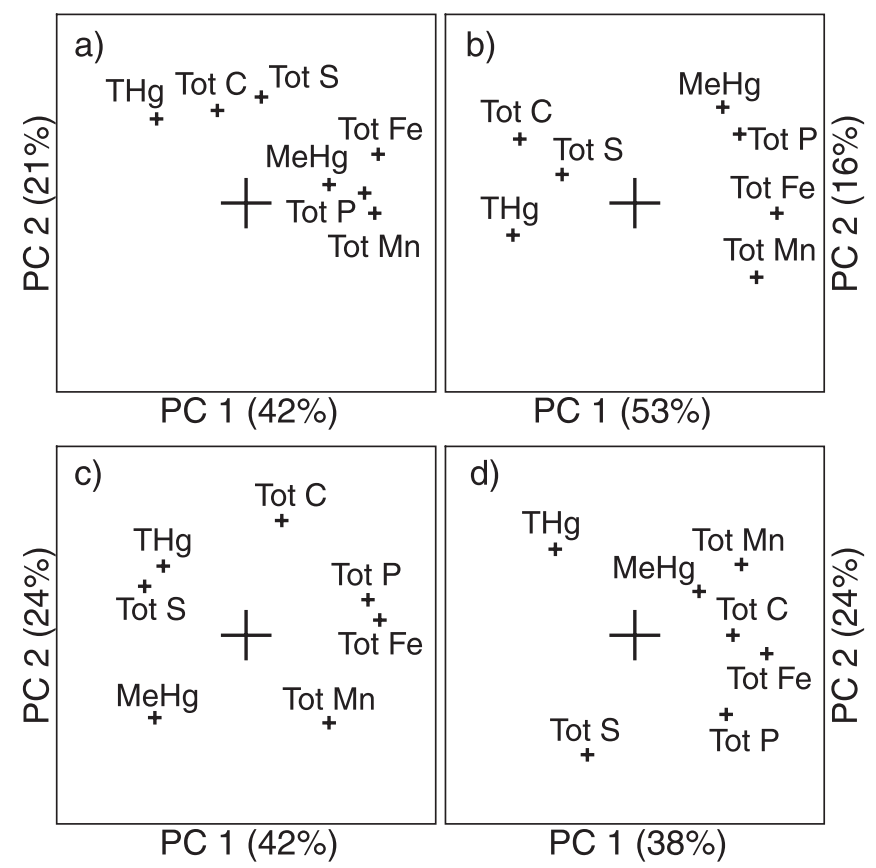

were only slightly altered using mean values instead of individual ones (data not shown).

The PCA suggested that $\mathrm{THg}$ (essentially $\mathrm{IHg}$ ) was bound to organic matter in the upper lake (Figs. $7 a$ and $7 b$ ), indicating that most of the THg was still associated with cellulose fibers and that the content of fiber explained most of the variation in $[\mathrm{THg}]_{\mathrm{SE}: 0-1 \mathrm{~cm}}$. Possibly, lignin residues, degradation products, and associated microorganisms increased the $\mathrm{Hg}$-binding capacity of the fibers (Ziomek and Williams 1989). It is also possible that $\mathrm{Hg}$ was present as inorganic sulfide. The projection of total $\mathrm{S}$ was closer to that of total $\mathrm{C}$ than that of total Fe (Figs. $7 a$ and $7 b$ ), suggesting that most of the $\mathrm{S}$ content was organically bound and hence that $\mathrm{Hg}$ was bound to organic matter via reduced S ligands. However, a positive relationship between organic matter and total $S$ could also result from a stimulation of sulfate reduction and $\mathrm{FeS}(\mathrm{s})$ formation by organic matter.

$\mathrm{MeHg}$ seemed to be associated mainly with $\mathrm{Fe}$ and $\mathrm{Mn}$, not with organic matter or sulfide, at both stations in the upper lake (Figs. $7 a$ and $7 b$ ). This indicated that once methylated, $\mathrm{Hg}$ had higher affinity for redox-sensitive HFO and HMO than for other sediment constituents, in accordance with the fact that $[\mathrm{MeHg}]$ was strongly correlated with [total $\mathrm{Fe}$ ] and [total $\mathrm{Mn}$ ] in the anoxic hypolimnetic water (Table 3). Apparently, methylation of $\mathrm{Hg}$, which in this case probably was coupled to anaerobic degradation of the fibers (Regnell et al. 1996), resulted in a transfer of $\mathrm{Hg}$ to $\mathrm{HFO}$ 
and HMO. One would expect that $\mathrm{IHg}$ was released as a result of organic matter decomposition, forming either DOC or sulfide complexes, and that $\mathrm{IHg}$ was also scavenged by HFO and HMO. Possibly, the fraction of the sediment THg that was released was too small to result in a positive correlation between $[\mathrm{THg}]_{\mathrm{SE}: 0-1 \mathrm{~cm}}$ and the variables [total $\left.\mathrm{Fe}\right]_{\mathrm{SE}: 0-1 \mathrm{~cm}}$ and total $[\mathrm{Mn}]_{\mathrm{SE}}$ : $0-1 \mathrm{~cm}$. Gobeil and Cossa (1993) found that $\mathrm{Hg}$ mobilized through diagenetic processes was negligible compared with the total content of $\mathrm{Hg}$ in $\mathrm{Hg}$-polluted estuarine sediments in the Laurentian Trough, Canada.

At both stations in the upper lake, [total P $]_{\mathrm{SE}}$ : $0-1 \mathrm{~cm}$ was the sediment variable showing the strongest covariation with $[\mathrm{MeHg}]_{\text {SE: } 0-1 \mathrm{~cm}}$ (Figs. $7 a$ and $7 b$ ). In addition to $\mathrm{MeHg}$ and $\mathrm{P}$ being associated with Fe, the level of both may have decreased because of increasing sulfide levels. Phosphorus is known to be displaced from Fe when the latter is converted to $\mathrm{FeS}$ (Roden and Edmonds 1997). MeHg may not be displaced to the same extent as a result of this conversion. Krabbenhoft et al. (1998) presented results indicating that $\mathrm{FeS}(\mathrm{s})$ has the ability to scavenge MeHg. However, when all sulfide-reactive $\mathrm{Fe}$ is depleted, free sulfide may compete with $\mathrm{FeS}(\mathrm{s})$ in the binding of $\mathrm{MeHg}$. Furthermore, free sulfide inhibits $\mathrm{MeHg}$ production. Thus, released $\mathrm{MeHg}$ will not be readily restored by new production. Another explanation for a positive $\mathrm{P}-\mathrm{MeHg}$ relationship is that $\mathrm{P}$ may stimulate activities of methylating bacteria.

In the lower lake, the absence of $\mathrm{Hg}$-polluted cellulose fibers may explain the weak relationship between $[\mathrm{THg}]_{\mathrm{SE}: 0-1 \mathrm{~cm}}$ and [total C] $]_{\text {SE: } 0-1 \mathrm{~cm}}$ (Figs. $7 c$ and $7 d$ ). However, because of the high affinity of $\mathrm{Hg}$ for organic matter, one would have expected $[\mathrm{THg}]_{\mathrm{SE}: 0-1 \mathrm{~cm}}$ and [total $\left.\mathrm{C}\right]_{\mathrm{SE}: 0-1 \mathrm{~cm}}$ to covary irrespective of the presence of cellulose fibers. A process that may counteract a tendency for a positive relationship between these variables is degradation of organic matter because this process will lead to a higher $[\mathrm{THg}]_{\mathrm{SE}: 0-1 \mathrm{~cm}}$ and to a lower [total $\mathrm{C}]_{\mathrm{SE}: 0-1 \mathrm{~cm}}$, provided that $\mathrm{Hg}$ is retained in higher proportion than the organic matter. At the shallow station, it was evident that [total $\mathrm{C}]_{\mathrm{SE}: 0-1 \mathrm{~cm}}$ decreased during summer, presumably because of organic matter degradation, whereas $[\mathrm{THg}]_{\mathrm{SE}: 0-1 \mathrm{~cm}}$ increased. At the deep station, organic matter degradation in the surface sediment seemed to have occurred at a rate similar to that at the shallow station, but $[\mathrm{THg}]_{\text {SE: } 0-1 \mathrm{~cm}}$ decreased during summer, indicating that $\mathrm{Hg}$ was released (Figs. $5 d$ and $5 j$ ).

Apparently at odds with HFO and HMO being important scavengers of dissolved $\mathrm{Hg}(\mathrm{II})$, [total Fe] $]_{\text {SE: } 0-1 \mathrm{~cm}}$ and [total $\mathrm{Mn}]_{\mathrm{SE}}: 0-1 \mathrm{~cm}$ were weakly or even inversely related to $[\mathrm{THg}]_{\text {SE: } 0-1 \mathrm{~cm}}$ at both stations in the lower lake (Figs. $7 c$ and $7 d$ ). At the shallow station, it is likely that the amount of $\mathrm{HFO}$ and HMO in the surface sediment was not limiting for the retention and (or) incorporation of $\mathrm{Hg}$, i.e., that there was always enough oxide to efficiently retain it. Thus, one should hardly expect [total Fe $]_{\text {SE: } 0-1 \mathrm{~cm}}$ and [total Mn] $]_{\text {SE: } 0-1 \mathrm{~cm}}$ to show strong relationships with $[\mathrm{THg}]_{\mathrm{SE}: 0-1 \mathrm{~cm}}$ at this station. Furthermore, most of the THg was probably bound to particulate organic matter, from which only a small fraction was transferred to HFO and HMO (Gobeil and Cossa 1993). At the deep station, $\mathrm{THg}$ may have been in the form of sulfide (Fig. 7c).

$[\mathrm{MeHg}]_{\text {SE: } 0-1 \mathrm{~cm}}$ showed a relationship with [total Fe $]_{\text {SE: } 0-1 \mathrm{~cm}}$ and [total P] $]_{\text {SE: } 0-1 \mathrm{~cm}}$ at the deep station in the lower lake that was totally different from that seen in the upper lake. Instead of clustering with total $\mathrm{Fe}$ and total $\mathrm{P}$ in the PCA, the projection of $\mathrm{MeHg}$ was opposing those of total $\mathrm{Fe}$ and total $\mathrm{P}$, suggesting that $[\mathrm{MeHg}]_{\mathrm{SE}}: 0-1 \mathrm{~cm}$ varied inversely

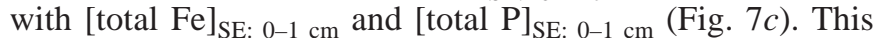
indicated that the retention of $\mathrm{MeHg}$ and inhibition of methylation by sulfide were not limiting factors for $[\mathrm{MeHg}]_{\mathrm{SE}: 0-1 \mathrm{~cm}}$, consistent with the fact that sulfide could not be detected in the hypolimnion. Under these conditions, i.e., when there is a surplus of sulfide-reactive Fe over sulfide, inhibition of $\mathrm{Hg}$ methylation and complexation of $\mathrm{MeHg}$ by sulfide would be low. The inverse relationship between [total Fe $]_{\text {SE: } 0-1 \mathrm{~cm}}$ and $[\mathrm{MeHg}]_{\text {SE: } 0-1 \mathrm{~cm}}$ could be a result of reductive release of $\mathrm{Fe}$ and methylation of $\mathrm{Hg}$ (II) both occurring under anoxic conditions (Figs. $5 b$ and $5 f$ ). The negative correlation between $\mathrm{MeHg}$ and total $\mathrm{P}$ is consistent with the fact that $\mathrm{P}$ is released when HFO is converted to $\mathrm{FeS}(\mathrm{s})$ by sulfate-reducing bacteria, known also to methylate $\mathrm{Hg}(\mathrm{II})$. A likely explanation for the fact that the two study lakes displayed different $\mathrm{MeHg}-\mathrm{P}-\mathrm{Fe}$ relationships was that sulfide-reactive Fe was depleted in the upper lake but not in the lower lake.

\section{THg in the surface sediment and the settling matter}

In both lakes, $[\mathrm{THg}]_{\mathrm{SE}}: 0-1 \mathrm{~cm}$ was higher than the integrated $[\mathrm{THg}]\left([\mathrm{THg}]_{\mathrm{INT}}\right)$ in the settling matter trapped $1 \mathrm{~m}$ above the sediment surface, except at the deep station in the upper lake (Fig. 8). At the latter station, $[\mathrm{THg}]_{\mathrm{SE}: 0-1 \mathrm{~cm}}$ and $[\mathrm{THg}]_{\mathrm{INT}}$ were similar, probably because of high resuspension, especially in conjunction with turnover. For the deep station in the lower lake, with a well-buried $\mathrm{Hg}$ peak and with only slightly increasing [ $\mathrm{THg}]$ with increasing sediment depth in the upper 0- to 10-cm layer (Fig. 6), it is questionable whether "old $\mathrm{Hg}$ " could explain the fact that $[\mathrm{THg}]_{\text {SE: } 0-1 \mathrm{~cm}}$ was 1.5 times higher than $[\mathrm{THg}]_{\mathrm{INT}}$ at the end of the study period. An alternative explanation is postdepositional enrichment, i.e., direct sorption of dissolved or colloidal $\mathrm{Hg}$ by the sediment surface. The hypolimnetic $\mathrm{Hg}$ enrichment (Fig. 9) indicated that the settling matter became depleted in $\mathrm{Hg}$ when it reached the anoxic hypolimnion. Upon reoxygenation, it seems possible that these particles would be undersaturated with $\mathrm{Hg}$ in relation to dissolved or colloidal $\mathrm{Hg}$ and that this would lead to direct sorption. Any such $\mathrm{Hg}$ could be released during the next anaerobic event, but perhaps not all of it.

In principle, direct sorption could have occurred at the other stations as well, depending on how fast equilibrium partitioning is reached, the presence of dissolved $\mathrm{Hg}$, the time it takes for particles to reach the sediment, and how stable are those conditions that affect the partitioning of $\mathrm{Hg}$ between particulate and dissolved forms.

Whole-lake studies performed in the Experimental Lakes Area, Canada, did suggest that for heavy metals reaching the epilimnion in a dissolved state, direct sorption could be significant (e.g., Hesslein 1987). Watras et al. (1995b) found that on average, $80 \%$ of $\mathrm{THg}$ passed $0.45-\mu \mathrm{m}$ filters in epilimnetic water from 23 lakes in Wisconsin. As already noted, organic matter decomposition would result in higher $[\mathrm{THg}]_{\mathrm{SE}}$, provided that $\mathrm{Hg}$ is more conservative than the organic matter during sediment diagenesis. However, only at the shallow station in the lower lake was there a significant 
Fig. 8. Temporal variation in $[\mathrm{THg}]$ in the surface sediment $(0-$ $1 \mathrm{~cm})(\boldsymbol{\square})$ and in the integrated [THg] (cumulative amount of $\mathrm{HgT}$ deposited/cumulative amount of dry substance deposited) in the settling matter $(\bigcirc)$ collected $1 \mathrm{~m}$ above the sediment-water interface during 1996 at the (a) upper lake shallow station,

(b) upper lake deep station, (c) lower lake shallow station, and (d) lower lake deep station. Bars represent $\pm 1 \mathrm{SD}(n=4$ or 5$)$. The values for settling matter are based on single samples.
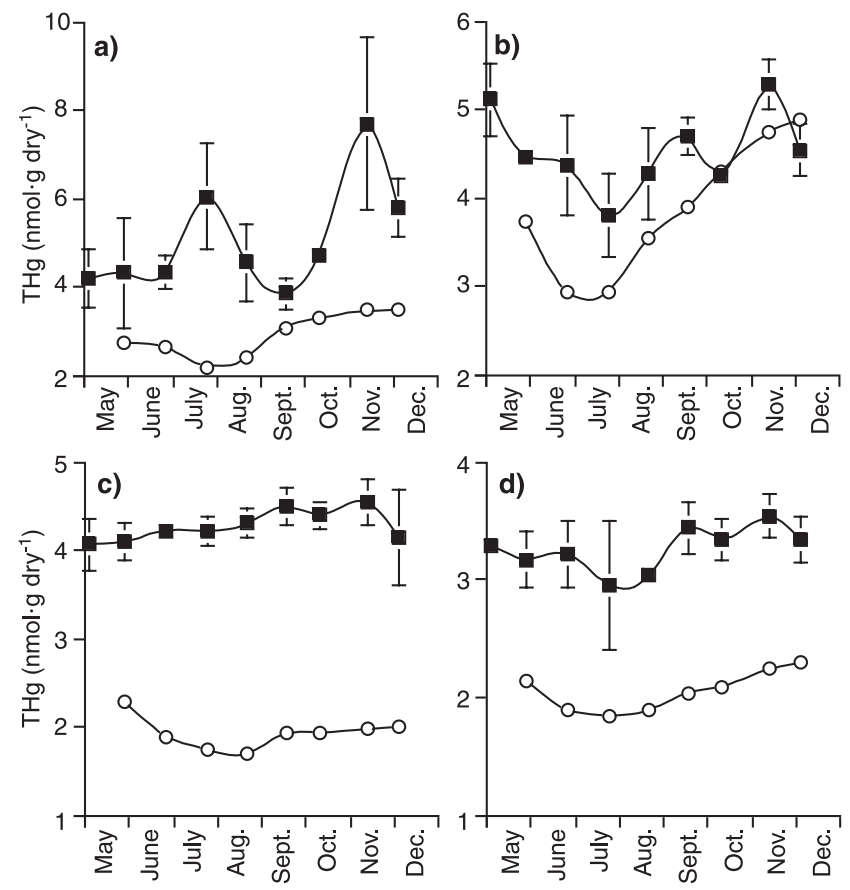

difference between $[\text { total } \mathrm{C}]_{\mathrm{SE}}$ and $[\text { total } \mathrm{C}]_{\mathrm{INT}}$ (data not shown).

\section{Effects of the sediment on the hypolimnetic $\mathbf{H g}$}

The water depth profiles suggest that release from sediment was more important for $\mathrm{MeHg}$ than for $\mathrm{IHg}$, especially in the upper lake (Fig. 10). However, as already mentioned, an apparent slow release of $\mathrm{IHg}$ from the sediment and from settling particles in the upper lake could be a result of rapid methylation.

In the upper lake, the decrease in $[\mathrm{MeHg}]_{\mathrm{SE}: 0-1 \mathrm{~cm}}$ could at most explain $60 \%$ of the major increase in $\mathrm{MeHg}$ in the $1-\mathrm{m}$ water layer closest to the sediment, provided that new production of $\mathrm{MeHg}$ in the sediment was negligible (Fig. 3a), leaving most of the buildup of $\mathrm{MeHg}$ in the anoxic bottom water unexplained. The contribution from the sediment could have been even less if the decrease in $[\mathrm{MeHg}]_{\mathrm{SE}: 0-1 \mathrm{~cm}}$ was the result of demethylation rather than of release of $\mathrm{MeHg}$ to the water. On the other hand, sediment at depths greater than the sampled layer could be an additional source of $\mathrm{MeHg}$. In the lower lake, $[\mathrm{MeHg}]_{\mathrm{SE}: 0-1 \mathrm{~cm}}$ increased rather than decreased during the buildup of $\mathrm{MeHg}$ in the hypolimnion (Fig. 3g).

High-resolution sampling close to the sediment-water interface would have been necessary to determine the flow of $\mathrm{MeHg}$ and $\mathrm{IHg}$ between sediment and water. Whether or not $\mathrm{MeHg}$ produced in the sediment constituted a significant part of the $\mathrm{MeHg}$ present in the anoxic bottom water, sedi-
Fig. 9. Temporal variation in $[\mathrm{MeHg}]$ and $[\mathrm{IHg}]$ in epilimnetic and hypolimnetic water (single samples) during 1996 in the ( $a$ and $b$ ) upper lake and ( $c$ and $d$ ) lower lake. $\square, 0.5 \mathrm{~m}$ for both lakes; $\square$, 6.5 and $11.5 \mathrm{~m}$ for the upper lake and lower lake, respectively.
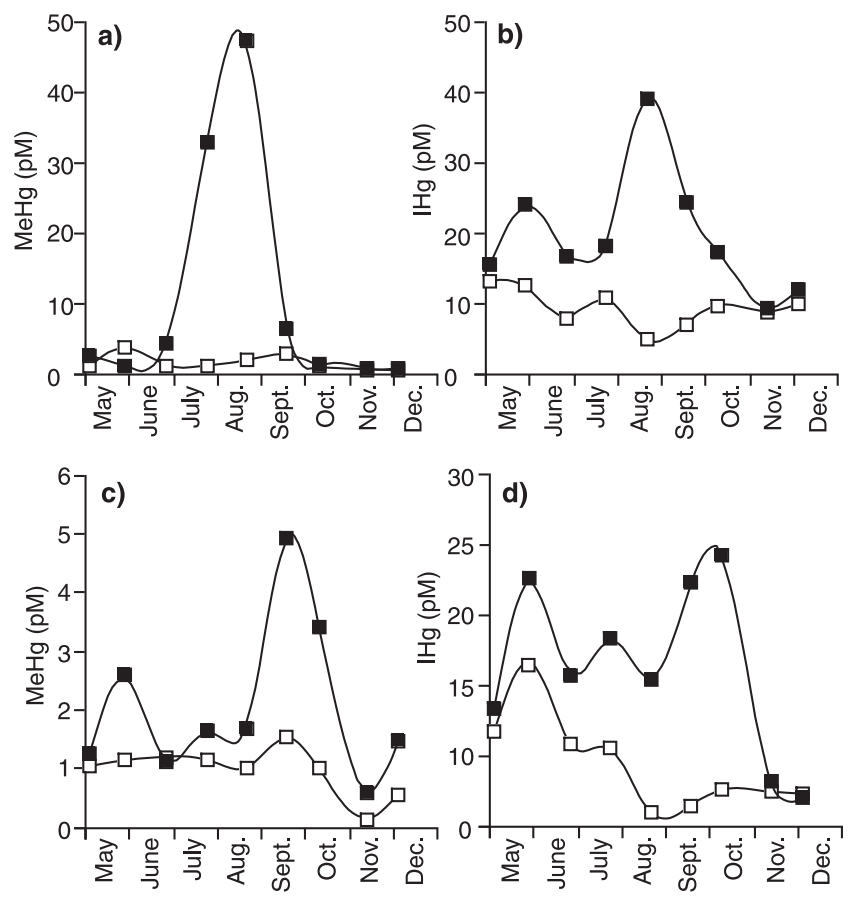

Fig. 10. Depth profiles of $[\mathrm{MeHg}]$ and $[\mathrm{IHg}]$ in the water column of the ( $a$ and $b$ ) upper lake and ( $c$ and $d$ ) lower lake on the dates indicated below (1996). The values are based on single samples. $\square$, July 24; $\mathbf{0}$, August 19; 田, September 17.

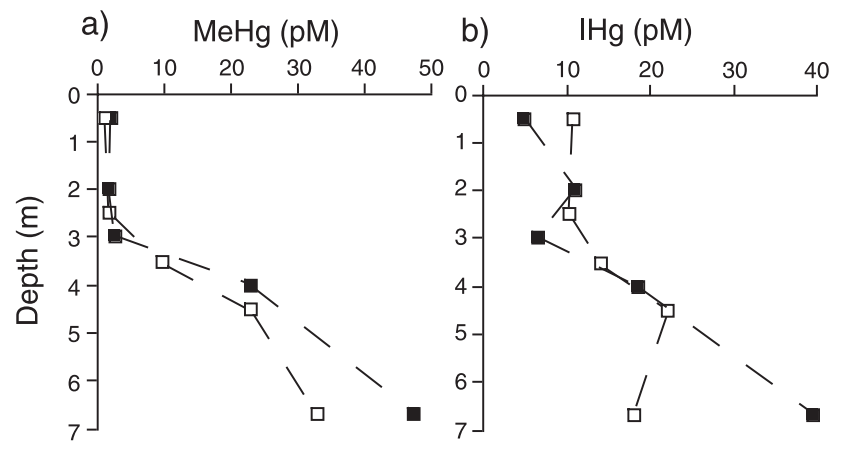

c) $\operatorname{MeHg}(\mathrm{pM}) \quad$ d) $\quad \mathrm{IHg}(\mathrm{pM})$

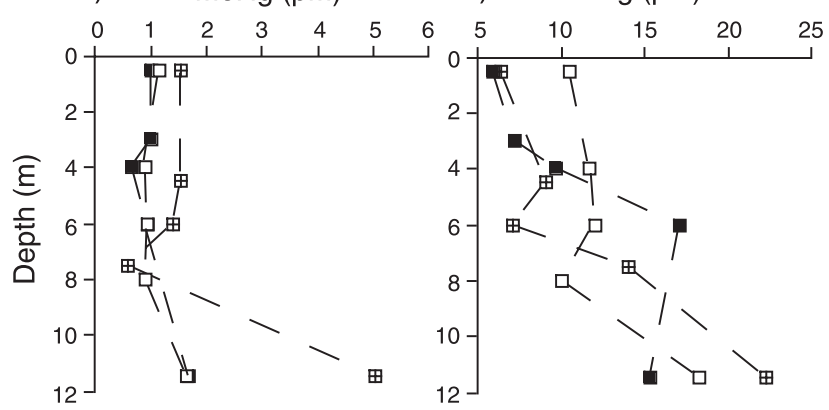


ment oxygen consumption and release of nutrients may have contributed significantly to the conditions in the overlying water that promoted both $\mathrm{Hg}$ methylation and release of $\mathrm{MeHg}$ from settling particles.

In the upper lake, $[\mathrm{MeHg}]$ reached $>50 \%$ of $[\mathrm{THg}]$ in the hypolimnetic water and $[\mathrm{MeHg}]_{\mathrm{SE}}$ reached $>10 \%$ of $[\mathrm{THg}]_{\mathrm{SE}}$, whereas in the lower lake, the corresponding percentages were 18 and $3 \%$. This indicated that the presence of cellulose fibers in the sediment greatly stimulated $\mathrm{MeHg}$ production in the upper lake, in agreement with a laboratory study of sediment and water from another lake (Regnell et al. 1996).

\section{Conclusions}

The presence of $\mathrm{MeHg}$ in the water was more redox sensitive than that of $\mathrm{IHg}$, as evidenced by the fact that [total $\mathrm{Fe}$ ] showed stronger correlation with $[\mathrm{MeHg}]$ than with $[\mathrm{IHg}]$ in the hypolimnetic water of both lakes. There were two possible links between [MeHg] and [total Fe] in the hypolimnetic water: (i) $\mathrm{MeHg}$ and its complexing ligands were sorbed by HFO; when HFO was reductively dissolved, leading to an increase in [total Fe], the solubility of $\mathrm{MeHg}$ increased and (ii) $\mathrm{MeHg}$ production was caused by the same microbial activity that caused dissolution of HFO, or coincided with it.

In the sediment of the upper lake, total Fe and Mn were positively correlated with $\mathrm{MeHg}$ because (i) $\mathrm{MeHg}$ was bound to HFO, HMO, and FeS(s), (ii) HFO and HMO made $\mathrm{Hg}$ more available for methylation by lowering free sulfide levels, and (iii) by scavenging free sulfide and dissolved organic matter, HFO and HMO decreased the MeHgcomplexing capacity of the water in contact with the sediment.

In the lower lake, there was an inverse relationship between $\mathrm{MeHg}$ and total $\mathrm{Fe}$ in the sediment at the deep station because anaerobic microbial activity caused reductive dissolution of HFO (leading to decreased levels of total $\mathrm{Fe}$ in the sediment) as well as increased net $\mathrm{MeHg}$ production (leading to increased levels of $\mathrm{MeHg}$ in the sediment). The effects of Fe described in points $i-i i i$ in the previous paragraph were never limiting for the retention or production of $\mathrm{MeHg}$ in the lower lake because of a constant surplus of sulfidereactive $\mathrm{Fe}$ in relation to sulfide.

$\mathrm{HFO}$ and HMO were important scavengers of $\mathrm{IHg}$ also, as evidenced by the fact that [ $\mathrm{IHg}$ ], [total Fe], and [total $\mathrm{Mn}$ ] increased simultaneously in the hypolimnion of the lower lake. The fact that [IHg] increased later than [MeHg], [total $\mathrm{Fe}$, and [total $\mathrm{Mn}$ ] in the hypolimnion of the the upper lake was a result of initial depletion of mobilized $\mathrm{IHg}$ by methylation.

We believe that our findings are valid for lakes that have received organic wastes or are naturally eutrophic in which anoxic conditions develop at the sediment-water interface. Especially in riverine lakes, factors controlling net sedimentation and net methylation of $\mathrm{Hg}$ are of high environmental concern because efficient withdrawal of $\mathrm{IHg}$ and $\mathrm{MeHg}$ in such lakes would lessen the $\mathrm{Hg}$ exposure of the biota downstream.

Our interpretation of the present results is, of course, not necessarily correct. To gain further information, we would like to go on with studies of phase associations of $\mathrm{Hg}$ in the sediment and in the water column and with studies of demethylation of $\mathrm{MeHg}$.

\section{Acknowledgments}

This study was supported by the Swedish EPA. MeHg and $\mathrm{THg}$ were determined by the laboratory of the Swedish Environmental Research Institute (IVL), Göteborg. The other chemical analyses were carried out by the Department of Plant Ecology, University of Lund, and by the municipal laboratory of Vetlanda. We would like to thank two anonymous reviewers for constructive criticism.

\section{References}

Benoit, J.M., Gilmour, C.C., Mason, R.P., and Heyes, A. 1999. Sulfide controls on mercury speciation and bioavailability to methylating bacteria in sediment pore waters. Environ. Sci. Technol. 33: 951-957.

Berman, M., and Bartha, D.R. 1986. Control of the methylation process in a mercury polluted aquatic sediment. Environ. Pollut. Ser. B, Chem. Phys. 11: 41-53.

Bloom, N. 1989. Determination of picogram levels of methylmercury by aqueous phase ethylation, followed by cryogenic gas chromatography with cold vapour atomic fluorescence detection. Can. J. Fish. Aquat. Sci. 46: 1131-1140.

Bloom, N.S., Coleman, J.A., and Barber, L. 1997. Artifact formation of methyl mercury during aqueous distillation and alternative techniques for the extraction of methyl mercury from environmental samples. Fresenius J. Anal. Chem. 358: 371-377.

Bloom, N.S., Gill, G.A., Cappelino, S., Dobbs, C., McCShea, L., Driscoll, C., Mason, R., and Rudd, J. 1999. Speciation and cycling of mercury in the Lavaca Bay, Texas, sediments. Environ. Sci. Technol. 33: 7-13.

Bodaly, R.A., Rudd, J.W.M., and Fudge, R.J.P. 1993. Mercury concentrations in fish related to size of remote Canadian Shield lakes. Can. J. Fish. Aquat. Sci. 50: 980-987.

Compeau, G., and Bartha, R. 1985. Sulfate-reducing bacteria: principal methylators of mercury in anoxic estuarine sediment. Appl. Environ. Microbiol. 50: 498-502.

Compeau, G., and Bartha, R. 1987. Effect of salinity on mercurymethylating activity of sulfate-reducing bacteria in estuarine sediments. Appl. Environ. Microbiol. 53: 261-265.

Cossa, D., Mason, R.P., and Fitzgerald, W.F. 1994. Chemical speciation of mercury in a meromictic lake. In Mercury pollution - integration and synthesis. Edited by C.J. Watras and J.W. Huckabee. Lewis Publishers, Boca Raton, Fla. pp. 57-67.

Craig, P.J., and Moreton, P.A. 1984. The role of sulphide in thenformation of dimethyl mercury in river and estuarine sediments. Mar. Pollut. Bull. 15: 406-408.

Davies-Colley, R.J., Nelson, P.O., and Williamson, K.J. 1985. Sulfide control of cadmium and copper concentrations in anaerobic estuarine sediments. Mar. Chem. 16: 173-186.

Davison, W., Woof, C., and Rigg, E. 1982. The dynamics of iron and manganese in a seasonally anoxic lake; direct measurements of of fluxes using sediment traps. Limnol. Oceanogr. 27: 987-1003.

Driscoll, C.T., Yan, C., Shofield, C.L., Munson, R., and Holsapple, J. 1994. The mercury cycle and fish in the Adirondack lakes. Environ. Sci. Technol. 28: 136-143.

Dyrssen, D., and Wedborg, M. 1991. The sulphur-mercury(II) system in natural waters. Water Air Soil Pollut. 56: 507-519.

Fonselius, S.H. 1983. Determination of hydrogen sulfide. In Methods of sea water analysis. Edited by K. Grasshoff, M. Erhardt, and K. Kremling. Verlag Chemie, Weinheim/Deerfield Beach. pp. 73-80.

Gagnon, C., and Fisher, N.S. 1997. Bioavailability of sedimentbound methyl and inorganic mercury to a marine bivalve. Environ. Sci. Technol. 31: 993-998. 
Gobeil, C., and Cossa, D. 1993. Mercury in sediments and pore water in the Laurentian Trough. Can. J. Fish. Aquat. Sci. 50: 1794-1800.

Hesslein, R.H. 1987. Whole-lake metal radiotracer movement in fertilized lake basins. Can. J. Fish. Aquat. Sci. 44: 74-82.

Hintelmann, H., Welbourn, P.M., and Evans, R.D. 1997. Measurement of complexation of methylmercury(II) compounds by freshwater humic substances using equilibrium dialysis. Environ. Sci. Technol. 31: 489-495.

Hintelmann, H., Keppel-Jones, K., and Evans, R.D. 2000. Constants of mercury methylation and demethylation rates in sediments and comparison of tracer and ambient mercury availability. Environ. Toxicol. Chem. 19: 2204-2211.

Horvat, M., May, K., Stoeppler, M., and Byrne, A.R. 1988. Comparative studies of methylmercury determination in biological and environmental samples. Appl. Organomet. Chem. 2: 515-524.

Hurley, J.P., Watras, C.J., and Bloom, N.S. 1991. Mercury cycling in a northern Wisconsin seepage lake: the role of particulate matter in vertical transport. Water Air Soil Pollut. 56: 543-551.

Jackson, T.A. 1998. Mercury in aquatic systems. In Metal metabolism in aquatic environments. Edited by W.J. Langston and M.J. Bebianno. Chapman and Hall, London, U.K. pp. 77-138.

Jackson, T.A., Parks, J.W., Jones, P.D., Woychuk, R.N., Sutton, J.A., and Hollinger, J.D. 1982. Dissolved and suspended mercury species in the Wabigoon River (Ontario, Canada): seasonal and regional variations. Hydrobiologia, 92: 473-487.

Kirkwood, A.E., Chow-Fraser, P., and Mierle, G. 1999. Seasonal mercury levels in phytoplankton and their relationship with algal biomass in two dystrophic Shield lakes. Environ. Toxicol. Chem. 18: 523-532.

Krabbenhoft, D.P., Gilmour, C.C., Benoit, J.M., Babiarz, C.L., Andren, A.W., and Hurley, J.P. 1998. Methyl mercury dynamics in littoral sediments of a temperate seepage lake. Can. J. Fish. Aquat. Sci. 55: 835-844.

Paquette, K.E., and Helz, G.R. 1997. Inorganic speciation of mercury in sulfidic waters: the importance of zero-valent sulfur. Environ Sci. Technol. 31: 2148-2153.

Poissant, L., Amyot, M., Pilote, M., and Lean, D. 2000. Mercury water-air exchange over the upper St. Lawrence River and Lake Ontario. Environ Sci. Technol. 34: 3069-3078.

Ravichandran, M., Aiken, G.B., Ryan, J.N., and Reddy, M.M. 1999. Inhibition of precipitation and aggregation of metacinnabar (mer- curic sulfide) by dissolved organic matter isolated from the Florida Everglades. Environ. Sci. Technol. 33: 1418-1423.

Regnell, O., Tunlid, A., Ewald, G., and Sangfors, O. 1996. Methyl mercury production in freshwater microcosms affected by dissolved oxygen levels: role of cobalamin and microbial community composition. Can. J. Fish. Aquat. Sci. 53: 1535-1545.

Regnell, O., Ewald, G., and Lord, E. 1997. Factors controlling temporal variation in methyl mercury levels in sediment and water in a seasonally stratified lake. Limnol. Oceanogr. 42: 1784-1795.

Roden, E.E., and Edmonds, J.W. 1997. Phosphate mobilization in iron-rich anaerobic sediments: microbial $\mathrm{Fe}(\mathrm{III})$ oxide reduction versus iron-sulfide formation. Arch. Hydrobiol. 139: 347-378.

Sokal, R.R., and Rohlf, F.J. 1995. Biometry. 3rd ed. W.H. Freeman and Company, New York.

Stordal, M.C., Gill, G.A., Wen, L.-S., and Santschi, P.H. 1996. Mercury phase speciation in the surface waters of three Texas estuaries: importance of colloidal forms. Limnol. Oceanogr. 41: $52-61$.

Suda, I., Totoki, S., and Takahashi, H. 1991. Degradaion of methyl and ethyl mercury by oxygen free radical-producing systems: involvement of hydroxyl radical. Arch. Toxicol. 65: 129-134.

Tipping, E., and Woof, C. 1983. Seasonal variation in the concentration of humic substances in a soft-water lake. Limnol. Oceanogr. 28: $168-172$.

Wallschläger, D., Hintelmann, H., Evans, R.D., and Wilken, R.-D. 1995. Volatilization of dimethylmercury and elemental mercury from River Elbe floodplain soils. Water Air Soil Pollut. 80: $1325-1329$

Wang, W., and Driscoll, C.T. 1995. Patterns of total mercury concentrations in Onondaga Lake, New York. Environ. Sci. Technol. 29: 2261-2266.

Watras, C.J., Bloom, N.S., Claas, S.A., Morrison, K.A., Gilmour, C.C., and Craig, S.R. 1995a. Methylmercury production in the anoxic hypolimnion of a dimictic lake. Water Air Soil Pollut. 80: $735-745$.

Watras, C.J., Morrison, K.A., and Host, J.S. 1995b. Concentration of mercury species in relationship to other site-specific factors in the surface waters of northern Wisconsin lakes. Limnol. Oceanogr. 40: 556-565.

Ziomek, E., and Williams, R.E. 1989. Modification of lignins by growing cells of the sulfate-reducing anaerobe Desulfovibrio desulfuricans. Appl. Environ. Microbiol. 55: 2262-2266. 